\title{
LUT
}

University

\section{Active sustainability actors: A life course approach}

Koistinen Katariina, Teerikangas Satu, Mikkilä Mirja, Linnanen Lassi

This is a Final draft version of a publication

published by John Wiley \& Sons, Inc.

in Sustainable Development

DOI: https://doi.org/10.1002/sd.1989

Copyright of the original publication: (C) 2019 John Wiley \& Sons, Ltd and ERP Environment

Please cite the publication as follows:

Koistinen K, Teerikangas S, Mikkilä M, Linnanen L. 2019. Active sustainability actors: A life course approach. Sustainable Development. 2019; 1-16. https://doi.org/10.1002/sd.1989

This is the peer reviewed version of the article, which has been published in final form at https:// doi.org/10.1002/sd.1989. This article may be used for non-commercial purposes in accordance with Wiley Terms and Conditions for Use of Self-Archived Versions.

This is a parallel published version of an original publication. This version can differ from the original published article. 


\title{
Active sustainability actors - A life course approach
}

\author{
Katariina Koistinen, ${ }^{1,2} *$ Satu Teerikangas, ${ }^{2,3}$ Mirja Mikkilä ${ }^{1}$ and Lassi Linnanen ${ }^{1}$ \\ ${ }^{1}$ Lappeenranta University of Technology, Sustainability Science, Lappeenranta, Finland; katariina.koistinen@lut.fi; \\ mirja.mikkila@lut.fi; lassi.linnanen@lut.fi \\ ${ }^{2}$ Turku University, Department of Management and Entrepreneurship, Turku, Finland; satu.teerikangas@utu.fi; \\ Katariina.koistinen@utu.fi \\ ${ }^{3}$ University College London, Bartlett School of Construction \& Project Management, London, United Kingdom; \\ s.teerikangas@ucl.ac.uk \\ *Correspondence: katariina.koistinen@lut.fi; Tel.: +35850413 1743
}

\begin{abstract}
There is increasing interest in the role of actors in the pursuit of sustainability transitions. In this paper, we adopt a life course perspective to explore active sustainability actors. To this end, we interviewed 16 professionals across private, public, and third sectors in Finland. The paper's main implication is in introducing a life course perspective to the study of active sustainability actors. Second, we propose a grounded model of active actors' sustainability engagement. The model details sustainability agency formation and maintenance dynamics. Going forward, our findings are a call for further research on sustainability agency, be it in its engagement, via life courses, or via the study of different actor types.
\end{abstract}

Keywords: sustainability transition; sustainable development; sustainability agency; life course; sustainability engagement.

"This is the pre-peer reviewed version of the following article: Koistinen $K$, Teerikangas $S$, Mikkilä M, Linnanen L. Active sustainability actors: A life course approach. Sustainable Development. 2019;1-16. https://doi.org/10.1002/sd.1989, which has been published in final form at https://doi.org/10.1002/sd.1989. This article may be used for non-commercial purposes in accordance with Wiley Terms and Conditions for Use of Self-Archived Versions." 


\section{Introduction}

There is increasing evidence that the world is heading toward an environmental crisis. Human perturbations have destabilized Earth-system processes at planetary scale (Rockström et al. 2009; Steffen et al. 2015). Securing a sustainable future calls for urgent, radical action in societies globally (Shaw et al., 2014; Le Blanc, 2015; Thapar et al., 2019; Zeiger et al., 2019). The sustainability transitions literature addresses these challenges (Köhler et al., 2019). Sustainability transitions refer to long-term, multi-dimensional, and fundamental transformations through which established socio-technical systems shift to more sustainable modes of production and consumption (Markard et al., 2012).

For sustainability transitions to succeed, the role of actors, i.e. agency, is critical. The sustainability transitions literature is placing increasing interest in the study of different forms of actors (Avelino and Wittmayer 2016; Fischer and Newig, 2016; de Haan and Rotmans, 2018; Wittmayer et al., 2017). To this end, Fischer and Newig (2016) identified a number of actor categories including niche, regime, landscape, governmental, market, civil society and intermediary actors. In parallel, scholars are exploring the interplay between agency and institutions (e.g. Fuenfschilling and Truffer, 2016; Antadze and McGowan, 2017). While the study of agency often focuses on individual actors (e.g. Pesch et al., 2017; Koehrsen 2018), recently, a body of knowledge on collective agency has emerged (e.g. de Haan and Rotmans; Mossberg et al., 2018).

Despite these ongoing advances, the sustainability transitions literature is critiqued for a seeming disconnect from the social sciences that have studied actors' behavior and behavioral change (Gazheli et al., 2015). As an example, there have been calls to examine individuals' psychosocial processes (Antadze and McGowan, 2017; Gazheli et al., 2015; Bögel and Upham, 2018). Moreover, the transitions literature adopts a seemingly static view of human behavior (Pesch 2015; van der Vleuten, 2018). Leading researchers have recently called for the need to further our appreciation of actors in sustainability transitions (Gazheli et al., 2015; Bögel and Upham, 2018; Upham et al., 2015; Upham et al., 2018; de Haan and Rotmans, 2018; van der Vleuten, 2018).

In an attempt to start to respond to these calls, this paper focuses on individuals actively engaged in sustainability transitions. We define an active sustainability actor as someone who, in his or her professional or private role, actively advances the sustainability agenda, i.e. is intentionally involved in furthering societal sustainability transitions. Inspired by extant theorizing on life courses (de Vries et al., 2017; Levy and Bühlmann, 2016), we adopt a life course approach to the study of active sustainability actors. The main research question driving our inquiry is: how does a life course approach enable appreciating sustainability-active actors' engagement toward the sustainability agenda? In order to answer this research question, we draw from interviews with 16 active sustainability actors.

The paper's main implication is in introducing a life course perspective to the study of active sustainability actors. Second, we propose a grounded model of active actors' sustainability engagement, which in particular details sustainability agency formation and maintenance dynamics. Third, our paper details sustainability agency formation. Going forward, our findings are a call for further research on sustainability agency, be it in its engagement, via life courses, or via the study of different actor types. 
The paper is structured as follows. We next shortly present the state of the art of research on agency in the sustainability transitions literature. Thereafter, we continue into life course theory. The third section introduces the research setting and methods. In the fourth and fifth sections, our findings

are presented. A discussion section concludes the paper, including the paper's implications to extant theorizing, limitations, as well as future research directions.

\section{Literature}

\subsection{Actors in sustainability transitions}

Frameworks on sustainability transitions can be considered to all include actors, and how, in one way or the other, they participate in systemic change (de Haan and Rotmans, 2018). Yet, the question of how actors relate to socio-technical transitions has been increasingly debated in recent years (Fischer and Newig, 2016; Avelino and Wittmayer, 2016; de Haan and Rotmans, 2018). A bulk of this literature has explored the interplay of agency and institutions (Fuenfschilling and Truffer, 2016; Antadze and McGowan, 2017). There is interest in actors' use of power in steering political or technological decisions (Stirling 2014; Avelino, 2017; Loorbach et al., 2017). Another recurring theme explores the role of agency in politics (Frantzeskaki et al., 2014; Kern, 2015; Mercure et al., 2016).

Sustainability transitions thus involve a wide variety of actors (Köhler et al., 2019; Markard et al., 2012). This is paralleled in the literature via an increasing interest in different actor types (Avelino and Wittmayer 2016; Fischer and Newig, 2016; de Haan and Rotmans, 2018; Wittmayer et al., 2017). In this respect, Fischer and Newig (2016) identify niche, regime, landscape, governmental, market, civil society and intermediary actors. Recently, a body of knowledge on collective agency has emerged (e.g. de Haan and Rotmans; Mossberg et al., 2018).

All the while, the question of agency remains debated, if not controversial, in the discipline (van der Vleuten, 2018; de Haan and Rotmans, 2018). For example, Gazheli et al. (2015) argue that the transition literature is disconnected from the social science disciplines that have accumulated knowledge about individuals' behavior and behavioral change. In their review of psychology in the transition literature, Bögel and Upham (2018) observe that psychological theories are rarely applied, while Upham et al. (2018) note that behavioral dynamics are often missing. What is more, according to Pesch (2015), the transition literature imposes an overly static image on actors. Van der Vleuten (2018) argues that actual actors and their behavior remain neglected. Taking a step further, Stephenson (2018) argues that the influence of culture on an individual's behavior and behavioral change are not sufficiently explored. Finally, Upham et al. (2018) note that structuration has been given scant attention.

In this paper, we seek to contribute to the study of agency in sustainability transitions via an appreciation of active individual actors' life courses. For the purposes of the study, we define an active sustainability actor as someone who, in his or her professional role, actively advances the sustainability agenda. While the sustainability transitions literature uses the terms 'agent' and 'actor' interchangeably (see e.g. Upham et al., 2018), we use the term 'actor' to explore actors' 
intentional actions, as the term emphasizes the act of 'doing'. In parallel, drawing on sociology classics, we conceptualize agency as an individual's capability to make free choices and to impact on one's environment (Giddens, 1984; Archer, 1995). We next proceed to presenting life course theory, better known as the life course perspective.

\subsection{Life courses}

Life course research is a widely used method to study individual lives and their trajectories. Research on life courses examines individuals' lives in time and place, applying historical and biographical perspectives (Settersten, 1999; Elder, 1994; Elder, 1998). A life course perspective is built on the assumption that present experiences inform subsequent stages in our lives; this forms part of an overall trajectory, capturing the evolution of an individual's life experience (de Vries et al., 2017). In addition to examining individual life paths, life course research also covers individuals' lives in relational contexts. In so doing, it seeks to appreciate the ways in which individuals share their life experiences through their close ties with one another (Elder, 1998). Mitchell (2013, p. 22) has defined a life course as "a sequence of socially defined events and roles that the individual enacts over time," adding that "these events do not necessarily proceed in a given sequence, but rather constitute the sum total of the person's actual experience".

The focus of life course research is on the context in which a person experiences life events. Life course research puts forth the idea that the consequences of life events are influenced by the timing of events, their perceived relevance, and their subjective experience (de Vries et al., 2001; Jang et al., 2002). A fundamental feature of the life course perspective is to focus on the relationship between life courses, the social environments and experiences of life course "passengers" (Levy and Bühlmann, 2016). For this reason, it is important to acknowledge the narrative descriptions of events in the context of an actor's life in addition to having a scalable assessment of her life events (de Vries et al., 2005). By integrating an event-based perspective with a personal life course narrative, it is possible to achieve an insider's perspective to an actor's life course (de Vries, 2013; de Vries et al., 2017).

Hence, the study of life courses allows for the creation of lifelines or timelines by using qualitative narratives about critical events or periods of time in an individual's life (de Vries et al., 2017). It is thus possible to gain meaningful inside information from individuals through their life courses and to create 'life event maps' that represent meaningful life events (de Vries et al., 2017). In this paper, 'narratives' refer to a body of events as well as the contextual details surrounding those events' occurrence (Bruner, 1986; Czarniawska, 1997; Pentland, 1999; Bartel and Garud, 2009). Narratives always include - in addition to the position, the action, and the outcome of a narrative individuals' own interpretations, agendas, and influences (MacLeod and Davidson 2007). What is more, although the lifelines narrated by actors may seem linear, in reality a lifeline is more likely a set of discontinuous events that have been subsequently assembled together in the individual's retrospective sense-making process.

As regards the positioning of agency during one's life course, Levy and Bühlmann (2016) argue that life courses result from individuals' personal agency. In other words, actors can use their free will to steer their life course. All the while, there is a need to distinguish between free-willed, agentic influence on one's own life course and the life course shaped by institutional, or environmental, influences (Levy and Bühlmann, 2016). 
The principles of and approaches to life course research have multidisciplinary origins including roots in sociology and psychology, biology, history, economics, and anthropology, as well as fields such as demography, criminology, epidemiology, health and policy sciences (Bernardi et al., 2018). Contemporary life-course research is thus a multidisciplinary field of study (Mortimer and Shanahan, 2003; Heinz et al., 2009; Levy and Bühlmann, 2016). Life course research has brought a longitudinal and developmental perspective into many substantive areas of study, including family formation, educational trajectories, and work lives (Mayer, 2019). However, to the best of our knowledge, a life course perspective has not been applied to the context sustainability actors. In this paper, we take up this challenge, adopting a life course perspective to the study of active sustainability actors' engagement toward the sustainability agenda.

\section{Methods}

In light of the lack of previous research on sustainability actors' life courses, we adopted a grounded theory-based qualitative research approach (Glaser and Strauss, 1967; Glaser, 1992). Such an approach is deemed suitable to the study of complex, social phenomena, unfolding over time (Glaser and Strauss, 1967; Easterby-Smith et al., 2008). Further, it befits instances, wherein a field of academic research has not yet paradigmatically established itself. Grounded qualitative research also suits exploratory and theory-building research, based on which subsequent quantitative research designs can be developed (Glaser and Strauss, 1967; Easterby-Smith et al., 2008).

The selection of interviewees was based on theoretical sampling (Glaser and Strauss, 1967). To begin with, we selected interviewees based on their sustainability activeness. In other words, we sought to interview professionals who, in their professional or private roles, actively advance the sustainability agenda. All the while, we sought to access sustainability actors in varied contextual settings (see Table 1). This led us to sample professionals across different industries and sectors. The range of sectors in our interviewee sample includes retail, energy production- and distribution, and grocery retail (see Table 1). Interviewees further represent private, public, and third (i.e., voluntary or non-profit) sectors.

Taking a look at our interviewees, both public sector actors in our sample were professionally in charge of the sustainability activities in their employing organizations. Both of the interviewed academics were actively pursuing a sustainability agenda in their professional roles, while only one of them formally holds a sustainability-related position. One interviewed entrepreneur was involved in the Finnish food system, while the other works in renewable energy. Interviewed NGO actors represented different environmental NGOs in Finland. Interviewed green consumers represent active individuals, taking deliberate sustainability action in their private lives. A slight majority of our interviewees, nine out of sixteen, held a sustainability related degree. Females represented ten of our sixteen interviewees.

In the context of these interviews, sustainability action refers to the interviewees' activities, undertaken in their professional and/or private roles, promoting a more sustainable future. 
Examples of such actions include leading sustainability initiatives in their work roles and living a sustainable lifestyle.

-Insert Table 1 about here-

We identified interviewees first based on initial desktop research, followed by professional recommendations, then via 'snowballing'. At the start of the interview, the interviewee was informed of the study's purpose, and that s/he had been identified as an active sustainability actor. In total, we conducted 16 interviews in 2016-2017. Toward the last interviews, 'theoretical saturation' began to be reached (Glaser and Strauss, 1967; Eisenhardt, 1989). This refers to the gradual saturation of knowledge on the studied subject area, in that as interviews proceeded, little additional information was gained other than minor, context-specific detail. As there is no 'definite point', where 'theoretical saturation' can be said to have reached, it is up to the responsible researcher to define the moment where additional interviewing provides little insight into the subject area. This is thus more a matter of 'degree' than 'exactness' (Glaser, 1992).

We adopted an open interview approach. Open interviews provide the interviewees a voice and allows them to create narratives and talk freely about their lives, interests, rationales, and strategies related to sustainability actions (Kvale, 1996). Open interviews also allow flexibility to react to each individual interview (Lincoln and Guba, 1985; Patton 2002). Our objective was further to exploit qualitative narratives regarding individuals' lifelines in order to find critical events or periods in individuals' lives that may have affected their sustainability engagement. The use of open interviews provides an avenue for this purpose. We applied a narrative methodology to find meaningful events during actors' life courses that had resulted in deliberate sustainability actions.

Since we followed an open interview approach, some questions varied across the interviews, while central themes and questions were always covered. Building on the premises of life course research (Elder, 1998; Settersten, 1999), our interview questions were concerned with actors' life courses from childhood to the present. This led us to probe each interviewee's relationship to sustainability from several points of view - starting from their development path toward sustainability, the obstacles they had encountered on this path, to how they perceived the current societal system visà-vis their sustainability engagement. We then elaborated on the critical events that had led to their deliberate engagement toward the sustainability agenda. We also asked about specific values that had influenced their lives. We probed into the connection between the interviewees' values and their actions with specifying questions. Interview themes are provided in Appendix A.

The majority (12) of our interviews were conducted face-to-face, three interviews were conducted via video Skype, and one via telephone. To ensure the anonymity of the interviewees and to stimulate openness during the interviews, the names of the interviewees and their affiliations are kept confidential. All interviews were tape-recorded. The duration of the interviews varied from 30 minutes to over two hours. The total recorded material thus amounted to 16 hours and 17 minutes. All interviews were transcribed by the lead author. This was helpful in view of data analysis.

In data analysis, we followed the principles of grounded theory (Glaser and Strauss, 1967; Glaser, 1992); i.e. analyzing our interview data via a bottom-up, iterative process based on the constant 
comparison of data, this leading to a conceptualization of the findings (Glaser and Strauss, 1967). There are several ways of grounded, inductive theorizing (Gehman et al., 2018). In this paper, we followed Gioia et al.'s (2012) approach, first developing a data structure, which is subsequently used to develop a conceptual, grounded model of the findings. This approach has gained prominence and legitimacy in leading management and organization journals in recent years (see e.g. Gehman et al., 2018), given that it provides visibility to the reader as regards the qualitative data analysis process and its outcomes.

Our data analysis took place iteratively in four broad phases. In a first phase, we proceeded to open coding the interview transcripts (Glaser and Strauss, 1967). This led us to identifying a set of recurring themes, i.e. first-order concepts in the data. In a second phase, we started to merge related first-order concepts, in so doing identifying higher-order categories, this resulting in second-order themes, and subsequently aggregate dimensions (Corley and Gioia, 2004). The aim of the third analysis phase was to structure the data into theoretical categories and to create a 'data structure' (Corley and Gioia, 2004; Gioia et al., 2012) representing the findings, see Figure 1. In a fourth phase, we developed the data structure into a grounded model, see Figure 2. In the next section, we start by presenting our findings using the data structure (part 1), followed by a presentation of the grounded model (part 2). In so doing, we follow Gioia et al. (2012)'s approach.

\section{Active sustainability actors' engagement toward the sustainability agenda}

In this section, we present our findings. Our data analysis process led us to identifying four aggregate dimensions explaining how a life course approach enables appreciating active actors' engagement toward the sustainability agenda. The four aggregate dimensions identified include (1) the actor's life path, (2) the actor's mind-set, (3) the actor as torn between individual vs. collective expectations, and (4) the actor's holistic lifestyle. The reader is encouraged to refer to Figure 1 below, which presents the data structure, based on which this section is structured, as well as Table 2, for an overview of second order themes, first-order concepts, and quotes.

-Insert Figure 1 about here-

-Insert Table 2 about here-

\subsection{Life path}

Based on our data, we find that an individual's life path helps to explain how her sustainabilityrelated agency is formed. Zooming closer, the aggregate dimension of life path describes the individual actor's personal growth toward sustainability agency via (1) upbringing and education, and/or (2) awakening moments. Taking a closer look, the interviewees could be divided into two categories: those who had grown vs. those who had awakened into sustainability agency.

\subsubsection{Upbringing and education}

Some interviewees had grown into sustainability agency. These interviewees' quotes concerning their upbringing and education portrayed a path from childhood events that had created an interest toward sustainability, leading in adulthood to deliberative sustainability action. To this end, some 
interviewees described how they had played in the forest as children or had spent their summers at country cottages in their youth. Interviewees concurred that their later engagement toward the natural environment had originated from these early, meaningful moments in life. The quote below illustrates childhood memories that influenced a young NGO actor:

"This somehow started in early childhood, when I played around in the forest a lot. Today I also understand the significance of forests through my work. I mean, the rainforests are irreplaceable, and the northern coniferous forests act as carbon sinks. But I still think that forests are also extremely important places for calming down and for healthy living." (NGO actor 1)

In addition to childhood memories, several interviewees stated that their time in school and higher education had influenced their subsequent engagement toward sustainability. Interviewees with a degree background in sustainability studies, for example, reflected upon the fact that sustainabilityrelated university studies felt like a calling. A few explained how they had pursued sustainability studies as front-runners at a time, in the 1980s and 1990s, when sustainability-related degree programs were either absent or only emerging. In the quote below, a middle-aged NGO actor describes her experiences in studies that awoke her interest in organic farming and the organic movement in general:

"My interest in biodynamic farming developed during my studies one summer, when I learned how much the forestry sector uses pesticides. There was this one guy who used so much pesticide every day, all the time, that it was insane. It also meant that we needed to clean our stuff every day, all the time, and take showers constantly." (NGO actor 2)

Finally, many of the interviewees also described how their professional development had shaped their views on sustainability, this strengthening their will to act toward a sustainable future. Further, the ongoing flow of information on sustainability further strengthened their resolve. Some interviewees stated that sustainability challenges were evident in their daily work. For example, one middle-aged sustainability professional in food retail mentioned that he was repeatedly facing environmental and social challenges considering the agricultural and manufacturing differences from certain Far Eastern countries that have not yet adopted similar regulations as Western countries:

"I think a lot about human rights, especially through the supply chain. I mean, if you think about those so-called risk countries in the Far East and in East Africa, you need to consider those issues immediately. So I've been thinking about these things a lot through my work." (Sustainability professional 3)

\subsubsection{Awakening moments}

For another set of interviewees, sustainability agency had been activated by awakening moments that had subsequently shaped their life courses. Some of these moments bore a positive connotation. As an example, an interviewed public sector actor described the experience of a golden eagle flying extremely low over him. This fleeting moment had triggered his lifelong interest in bird watching: 
"One pivotal coincidence happened when I was walking down the shore in Munkkiniemi [a wellknown shore in Helsinki]. I saw a young golden eagle flying really low over me. This moment impressed me a lot. Actually, I spent the whole winter there using my binoculars. I saw the eagle there few times and I photographed it. This moment initiated my eager bird watching hobby, which has continued until present days." (Public actor 2)

Some interviews, in contrast, included elements of crisis that had radically altered the trajectory of the actor's life course. Most of the interviewees also portrayed learning moments or points that had led to a chain reaction where their sustainability action had gradually started to grow. For example, one young green consumer described how he had awakened to taking deliberative sustainability action after he had calculated his carbon footprint; he was simultaneously forced to consider the consequences of his actions while thinking of possibilities for making a difference:

"I had heard about climate change. But I didn't want to find more about it, since that would have meant that one could have started to act against it. Or, actually, I was afraid that the climate change would be such a thing that it would start to trouble me, if I would think about it more. So, I felt that it was easier just not to think. I guess, in a sense, I thought that 'one person can't do anything'. The final awakening happened in the university, where these things were discussed. ... At the time when I was assigned to calculate my own carbon footprint, I started to think what influences on the carbon footprint. I realized that actually it was simple to reduce the footprint. By simple everyday actions." (Green consumer 2)

Some of the interviewees' awakening moments related to an eye-opening experience of witnessing the deprivation of nature, or as an awakening moment in terms of being existentially frightened about the future. These moments shaped the actors' life courses in such a way that they became intentionally engaged toward a sustainability agenda. A young sustainability professional in the energy industry described her awakening moment as follows:

"These things started to interest me when I was a teenager. Actually, they started to frighten me. At the time, the main thing was climate change. I can remember how unpleasant it was. It was 2006 when Al Gore's movie [An Inconvenient Truth] came out. I couldn't even watch it, and I was so scared -[climate change] felt like such a huge problem." (Sustainability professional 1)

\subsection{Mind-set: belief vs. critique}

Our second aggregate dimension relates to the actors' mindsets. In this respect, we observed the interviewees' mindset to be torn between a belief in a sustainable future, contrasted against a mindset critical of the existing societal system.

\subsubsection{Belief in a sustainable future}

Interviewees described how their hope for a more sustainable future had led them to engaging in sustainability-related action. The majority of our interviewees believed that the future would be brighter. All the while, they stated how, in parallel, they were also seriously concerned about the current state of the world vis-à-vis sustainability. For example, one interviewee portrayed how she constantly assesses sustainability-related threats in her professional role; this led her to experiencing that all the ingredients for an ecological catastrophe are in place. Despite these 
negative feelings, she maintained a firm belief that society as a whole would find solutions to these threats. A young interviewee working in a NGO described how she does not hold a particularly optimistic view of the future, but she nevertheless stated that without a belief in positive change, she already would have given up on the sustainability agenda:

"...I have learned what a huge amount even a small number of people can achieve. It is extremely important for me to maintain hope. I guess I could not do anything if I did not believe that we were still capable of solving these problems. But it will still demand a pretty big change in our collective thinking. " (NGO actor 1)

Another recurring theme in the interviews was a determination to create a better future for future generations. This theme created more belief in their sustainability actions for the interviewees. As another female working in a NGO stated, how it is important for her to try to ensure that future children would be able to live decent lives:

"At the end of the day, I can say to the kids, 'Hey, at least I tried." (NGO actor 3)

\subsubsection{Critical of the existing system}

In addition to their belief in shaping the current system for the better, the actors portrayed a distinctively critical mind-set. This critique was targeted toward the existing societal system. Many actors described how "something should be done to the existing system", a system based on an economic logic of continuous growth and increasing consumption. They noted how critical it is to limit growth and consumption. Yet, these subjects are not widely discussed outside of niche communities that criticize capitalism. A young green consumer expressed his concern about the oil industry, where the debate remains focused on the fear of running out of oil, rather than on creating competitive, and more sustainable, alternatives to oil:

"Just now I thought about energy policy, and how it is married with our economics. For example, we can talk about how wind energy and solar energy are unprofitable, and how taxpayers subsidize these things. I mean, we could do so much for this [type of energy]. I mean, really, if we would honestly talk about how much countries have spent in support of oil drilling over time, it would be a huge topic." (Green consumer 1)

The criticism expanded to concern consumption in general. Another young green consumer actor stated how any type of consumption harms the environment. In addition, an interviewee working in academia pointed out criticism toward consumption by hoping for a new economic paradigm in which environmental values would be as important as economic ones:

"We are living in a culture of dishonesty of intelligence, and this culture of dishonesty of intelligence is still in charge, since earlier, the increasing material wealth actually brought more wellness." (Academic 1)

\subsection{Individual vs. collective expectations}

The third aggregate dimension describes how the interviewees experienced being torn between individual and collective-level expectations. 


\subsubsection{Intrinsic motivation overcomes collective expectations}

Many interviewees experienced their intrinsic motivation toward sustainability to be stronger than external expectations. Most of the interviewees had had to undergo difficulties in order to engage or maintain their engagement toward the sustainability agenda. For example, some had felt forced to change their professional positions or career paths in order to connect their work with sustainability. One respondent described how her professional career had been scattered; her longest contract of employment had lasted only two years. She explained that this related to her commitment to work in sustainability-related positions. An interviewee, currently working in the academia, told that he needed to establish a firm in the 1990's to promote environmental issues. Since, at the time, it was unheard in traditional companies:

"There was a market demand, which resulted, in a way, that we needed to start our own firm, since no already-established company could have done this-because the already-established ones didn't want to do this. If you think, for example, of XYZ [a consulting firm, name removed for reasons of confidentiality], they couldn't even think that they would do environmental management consulting, since those were 'wingnut' kinds of things. I mean, really, at the time, environmental management consulting was a wingnut thing. So there was no other way to execute this mission than to establish a firm with a few friends." (Academic 1)

A strong intrinsic motivation and belief that one is "doing the right thing" helped the interviewees to remain resilient, even if the surrounding social system, be it one's working or social environment, or the society at large - was not always fully supportive of their sustainability-related actions. For example, an interviewed academic recalled how she had actually grown stronger through her tribulations; she stated how it would not have mattered if she lacked money or a good position, since she would have been happy without any material status. One of the interviewed NGO actors described how she had encountered a lot of bullying during her early years because of her calling for sustainability. As she was certain of her choices, she maintained her stance despite the lack of support from her colleagues, peers and friends:

"I found it really nice to start doing these sustainable-development tasks. But since my background is in business administration, where the values are very techno-economic in nature, many of my friends from that world were like, 'What crazy stuff is that?' since they did not know at the time what sustainability was. Fortunately nowadays, people appreciate this kind of work. Even the skeptics appreciate our work, even if they do not want to do it themselves. I still frequently receive hate mail, though, most recently today. But I know that we're doing the right thing, and then I have this group. It is great to just open this door and come here-I have an organization where we all pull together, and that is unbelievably great. I simply believe that when we go forward in a positive and goal-oriented way, we will make a change." (NGO actor 4)

\subsubsection{The feeling of inadequacy}

Whereas interviewees described their dedicated commitment toward a sustainability agenda as resulting from a strong intrinsic motivation, some of the narratives had a different tone: several actors shared the concern that their individual actions do not suffice with respect to securing a sustainable future. Many of the interviewees had also learnt to deliberately restrain themselves 
from engaging toward too many sustainability issues in order to prevent from burning out. For example, a middle-aged public actor in a medium-sized city described how she had taught herself to be gentler with herself and to keep in mind that she did not need to save the world by her own actions only. The quote below illustrates how a public sector actor needed to set personal boundaries in order to avoid holding too much burden over the state of the world:

"Realistically, we need to set boundaries for ourselves in order not to burden ourselves too much, or even to burn out. At the end of the day, I still believe that even one person can make a difference. I pay special attention to not doing any work during the evenings and on the weekends. Instead, I do something nice; it is crucial to have something else, too. It brings me some peace that on Fridays, I know I have done important things, and now I can concentrate on something else. When I was in my twenties, I was really close to burning out, so it was necessary for me to learn my own limits." (Public actor 1)

The interviewees also indicated that they often felt that there was much more to do and that their own input was simply inadequate. For example, one sustainability professional described how, if she allowed it to occur, she felt a constant sense of world-weariness. This sensation of inadequacy, however, also led actors to remain engaged in sustainability transitions. Interviewees told that they need to stay active in their sustainability agenda, if others are not acting. One sustainability professional described her feeling of inadequacy as follows:

"Sometimes I wonder how I can make a difference if, in Finland, for example, 200 people think these things, when somewhere else, 2 million people are acting in the opposite way." (Sustainability professional 2)

\subsection{A holistic lifestyle}

As our final aggregate dimension, we identified the actors' holistic lifestyles. This describes how thoroughly sustainability is included in the everyday lives of the interviewees. What is more, it is via a holistic lifestyle that actors are able to maintain their sustainability engagement.

\subsubsection{Value-action coherence}

The sustainability actions of everyday life, such as opting for a vegetarian diet or choosing to ride a bicycle instead of driving, appeared as self-evident and integral parts of the interviewees' personal lives. For example, one of the interviewed sustainability professionals stated how she commutes to work by bicycle daily, be it in winter or summer. The interviewed green consumer pondered if recycling is a sustainability act, since he considered it as self-evident:

"'Every time you buy something, you try to make better choices. Well, today I put cardboard boxes in the recycling bin. But, you know, those are the kinds of things you've always done, and you don't even think of those as being environmentally friendly acts." (Green consumer 2)

Several interviewees indicated how they aimed to act on what they believed. A repeating notion during the interviews related to how actors' values reflected their actual behavior. Several examples of such situations were provided. For example, both of the green consumers pointed out that they did not want to do anything harming either animals or the environment. One of the public 
actors interviewed described how she felt that it was only natural that she used renewable energy in her household, rode a bicycle to work, recycled everything she could, and grew some of her food herself. Another public actor observed that it was a privilege to be able to act and work according to one's values:

"I find that I'm very lucky and privileged, since I'm able to work in accordance with my valuesI mean, environmental protection and taking care of all that-people here have a good place to work." (Public actor 2)

\subsubsection{Socio-physical coherence}

Socio-physical coherence was manifest in the interviewed sustainability actors' lifestyles. In addition to being ecologically minded in their professional and private roles, the interviewed actors maintained a socially sustainable lifestyle. To this end, interviewees described how, overall, taking care of their personal lives helped them to stay resilient and to continue with their engagement toward the sustainability agenda. For example, they highlighted the role of exercise, diet and sleep. The young green consumer described how he systematically aimed to eat a healthy diet, avoid alcohol or tobacco, and generally lead an active lifestyle:

"I almost never drink alcohol, I don't smoke, I try to eat a healthy diet, I exercise a lot, and I prefer an active everyday life." (Green consumer 2)

Another recurring feature across the interviews was the exercise of yoga. This appeared to be an interest that supported many interviewees in maintaining their agency. For example, a middle-aged sustainability professional spoke of how her father had been influenced by the yoga philosophy in the 1970s, and for that reason, the whole family had eventually adopted a vegetarian diet, which was revolutionary at the time. Another example was an academic who described yoga as an incentive for her sustainability actions:

"I have practiced yoga quite long - maybe around 12 years. I think this [sustainability actions] has come through yoga, since I have not changed anything else during the past 15 years. I think yoga is the only thing that has changed my lifestyle and me systematically. Yoga has taught me to eat healthier, sleep better and to be more positive. To be like a better version of me. I would say that yoga has cleansed my body and also my mind and by doing that it has helped me to make wiser choices. It [yoga] has made me realize that nothing else matters than do we have this planet anymore" (Academic 2)

\section{A grounded model of sustainability engagement}

In this section, we present our grounded model of sustainability engagement. In so doing, we follow the Gioia approach (Gioia et al., 2012) of grounded qualitative analysis that recommends moving from an initial data structure (see Figure 1) toward a conceptual model of the findings (see Figure 2). In practice, in this analysis phase, we sought to appreciate how the four identified aggregate dimensions (i.e. life path, mind-set, individual vs. collective expectations, and holistic lifestyle) describing the interviewees' engagement toward the sustainability agenda relate to one another. This final step in our analysis led us to further distinguishing two axes, namely (1) agency 
formation, and (2) agency maintenance, under which the four aggregate dimensions could be mapped, see Figure 2. Taken together, agency formation and maintenance explain the actors' engagement toward the sustainability agenda.

In our analysis, however, we observed that the four aggregate dimensions mapped differently mapped onto agency formation and agency maintenance. The dimension of life path appears to be essential in explaining agency formation. The dimensions of 'torn between individual vs. collective expectations' and 'a holistic lifestyle' describe agency maintenance. Interestingly, the aggregate dimension of 'mind-set' explains both agency formation and maintenance.

-Insert Figure 2 about here-

As regards agency formation, the aggregate dimension of 'life path' provides an over-arching explanation leading actors to engage in deliberate sustainability action. Our findings thus imply that agency formation occurs either through an actor's upbringing and education or through remarkable events that change the actor's course of life. Many of the interviewed actors described memories related to sustainability - e.g. as regards childhoods in nature - and stated that their interest in sustainability had grown over their life course. Others stated that their interest had been awakened, or markedly increased, owing to a meaningful life event - for example from seeing a lock-in mechanism of deforestation in practice.

In contrast, the aggregate dimensions of 'torn between individual vs. collective expectations' and 'holistic lifestyle' helped actors to maintain their engagement in sustainability transitions. On the one hand, the aggregate dimension of 'torn between individual vs. collective expectations' showed how actors engaged in sustainability action based on their intrinsic interests. Strong individual beliefs, often originating from the actors' interests, helped to overcome collective expectations. For example, some of the interviewees stated that their willful belief in their cause (i.e. a more sustainable future) helped them to stay resilient and to overcome potential hurdles. Many actors had chosen their career paths because of sustainability interests. Some actors had moved onto entirely new careers, since their earlier professional paths had not reflected their sustainabilityrelated interests. Even though the actors' sustainability actions varied, and they strongly believed that individual actions mattered, there were numerous mentions of a sense of inadequacy. Sometimes they even questioned the influence of an individual on the global scale. Nevertheless, the feeling of inadequacy appeared to be a motivation for actions, urging actors to maintain their sustainability engagement. Further, it influenced the actors' life paths. The feeling of inadequacy was the most recurring theme in the interviewees' life course narratives.

On the other hand, the aggregate dimension of 'holistic lifestyle' unveils how actors' lifestyles were so strongly connected with their values that their daily sustainability actions, such as using public transportation or decreasing consumption, appeared to the interviewees as self-evident and a natural part of life. In addition, interviewees often preferred healthy lifestyles; this helped them to wind down, regain energy and stay resilient. A holistic lifestyle helped to maintain the actors' sustainability engagement.

Interestingly, the aggregate dimension of 'mind-sets' relates to both agency formation and agency maintenance. The actor's mind-set explains deliberate action; actors often described their reasons 
for engaging and staying engaged in deliberate sustainability actions via the desire to create a better future for forthcoming generations. Moreover, though the interviewees were aware of the sustainability threats that the world is facing, they nevertheless maintained a firm belief that the future would be more brighter. This mindset helped them to maintain their engagement toward the sustainability agenda. In parallel, many were vocally critical of the existing system. This critical mindset had initially led the interviewed actors to engage in sustainability actions. All the while, interviewees explained that the problems of the existing system also kept them engaged in sustainability action. Thus, their critical mindset both helped to form and to maintain their sustainability agency.

Overall, the aggregate dimension of 'life path' portrayed a meta-level dimension related to the other aggregate dimensions. This may in part stem from the fact that our interview questions focused on actors' life courses. One's life course and individual growth during life - whether the growth is the result of upbringing and education or through awakening moments - typically encompasses an individual holistically. Hence, our other aggregate levels - actors' mind-sets, the dichotomy individual vs. collective expectations, and actors' holistic lifestyles - seemed to derive from actors' life courses.

\section{Discussion}

\subsection{Research implications}

The paper offers three tentative and explorative insights to extant theorizing on the role of individuals as actors in sustainability transitions.

The paper's main implication to extant research is in offering a life course perspective to appreciate active sustainability actors. Despite the increasing body of knowledge on actors in sustainability transitions, this literature rarely connects with the social sciences that have studied behavior and behavioral change (e.g. Pesch 2015; Gazheli et al., 2015). What is more, previous research on sustainability transitions arguably retains a static view on agency (e.g. Pesch 2015; Gazheli et al., 2015). In this paper, we started addressing these gaps by studying active actors' sustainability engagement. We used the life course perspective as our theoretical, methodological, and analytical lens. To the best of our knowledge, this is one of the first papers to undertake a life course approach to the study of active sustainability actors. Such an approach enabled a deep-dive into active sustainability actors' lives and their sustainability engagement.

The paper's second implication to extant research is in suggesting a grounded model of actors' engagement toward the sustainability agenda. An individual's life path, the dichotomy between individual vs. collective expectations, the actor's mindset, as well as her holistic lifestyle seem to explain an individual's sustainability engagement. Upon closer look, though, we observed that these four dimensions mapped differently onto sustainability agency formation and maintenance. For one, an individual's life path appears essential to sustainability agency formation. For another, the individual's mindset, fluctuating between belief and critique, explains both agency formation and maintenance. Third, the actors' holistic lifestyles and the experience of being torn individual vs. collective expectations describe how actors maintain their sustainability agency. 
The paper's third implication is in providing insights sustainability agency formation. We identified two paths for agency formation: sustainability agency develops either through upbringing and education or through awakening moments. The dichotomy between upbringing and education vs. awakening moments is widely discussed in sociology and social psychology. This dichotomy is typically portrayed at different levels of life courses: at the level of historical change - i.e. the timing of lives does not happen in a social vacuum - and at the level of life experience (e.g., Elder, 1973; Elder, 1994). Within the transition-management framework, Loorbach et al. (2016) observe that crises tend to create space for agency and consequently for system transitions. The understanding of the influence of historical change and life experiences is thus emerging in the transition literature. To our knowledge, however, an understanding of individuals' life courses and its effects on sustainability agency formation has been absent. Hence, our findings provide early indications that the life development path (as acknowledged in other contexts in other social sciences) affects the formation of sustainability agency. Going forward, our findings are a call for further research on sustainability agency.

\subsection{Limitations and future research directions}

This study has several limitations. First, our study set out to examine active actors of sustainability transitions; this implies that a study on less active, or perhaps incumbent, representatives of the socio-technical system is warranted. The transition literature emphasizes the dichotomy between regime and niche actors (Geels and Schot, 2007; Fischer and Newig, 2016), though regime actors appear to have competing rationales (Bakker, 2014; Fischer and Newig, 2016). More research on different types of actors is in need. In order to better understand actors who are somewhere between activity and passivity, the study of such 'in between' actors also deserves attention.

In addition, we did not explicitly examine the differences between actors' varying roles in life. Actors may act differently in their personal vs. professional lives. This ambivalence about actors' different roles in life in relation to their sustainability actions deserves further study. This relates to the debate on how to conceptualize and integrate actors and agency into the study of sociotechnical transitions (Fuenfschilling and Truffer, 2016). We encourage future research to focus on the possible differences in actors' professional vs. private roles, as they engage in sustainability transitions.

A third limitation concerns the study's setting, which took place in the context in one country, namely Finland. This limitation indicates that our findings may as such not apply in other socioeconomic settings. Results from a highly industrialized Western country are likely to provide implications for active actors' sustainability engagement in similar countries. At a conceptual level, though, we expect our findings to offer tentative insights and inspiration across contexts. Future research on active sustainability actors and their life courses, set amidst different sociocultural and economic contexts, is called for.

A fourth limitation relates to the seeming linearity of the life courses observed. This linearity is partly explained by the nature of life course studies: individuals tend to create linear paths retrospectively when asked, whereas the reality is likely more disorganized and messy. The explicit narratives and descriptions we obtained on actors' life courses indicated that the actors were capable of describing their life paths and explaining their actions. This finding may also mark a difference between the active actors of sustainability transitions and others. The interviewed active 
actors had consciously considered their positioning in the socio-technical system and had deliberate, intentional reasons for engaging in sustainability action. In other words, they were consciously steering their life courses toward sustainability engagement, in so doing exercising their sustainability agency (Levy and Bühlmann, 2016). One reason for this high level of selfknowledge may be explained by the fact that the actors had encountered many challenges during their life courses, and they had been forced to (re)consider their choices. This high level of selfknowledge might also in part explain the resilience that our interviewees manifested.

A final limitation relates to the relatively small sample size. Given that the studied phenomenon sustainability actors' life courses - is relatively unknown, we adopted a qualitative, grounded theory based research approach. Such an approach is recommended in the study of social phenomena, where current theorizing is mixed or scarce, or when the goal of the research is to gain an in-depth appreciation of individuals' perspectives (Glaser \& Strauss, 1967). Interviews were capped at 16, as theoretical saturation was reached (Glaser, 1992). This is not an objective point, but rather a sense that the researcher has little to gain from conducting additional interviews. We recommend subsequent interview-based studies in other contextual settings, or developing these findings into survey instruments for testing using quantitative methods. Our research has provided initial implications to understand how sustainability engagement, and in particular sustainability agency forms and is maintained. Going forward, there is a need for further research on agentic engagement in sustainability transitions. 
Appendix A

THEMES OF THE INTERVIEWS

Who is the actor, and where does he/she come from?

What is his/her relationship to sustainability and to sustainability transitions?

-What is the timeline regarding this relationship?

-What situational factors influence this relationship?

-What rationales influence this relationship?

How have the actor's sustainability actions developed over time?

Why is the actor interested in sustainability?

What were the actor's most recent actions related to sustainability?

What has challenged the actor's sustainability path?

How does the actor perceive the current system?

How does the actor perceive the future of sustainability?

What values does the actor have?

- How are these values manifest in the actor's life? 


\section{References}

Antadze, N., McGowan, K. (2017). Moral entrepreneurship: Thinking and acting at the landscape level to foster sustainability transitions, Environmental Innovation and Societal Transitions, 25, 113.

Archer, M. (1995). Realist Social Theory: The Morphogenetic Approach, Cambridge University Press, 368 p. ISBN 0521484421.

Avelino, F. (2017) Power in Sustainability Transitions: Analysing power and (dis)empowerment in transformative change towards sustainability, Environmental Policy and Governance, 27, 505520. doi: 10.1002/eet.1777

Avelino, F., Wittmayer, J.M. (2016). Shifting Power Relations in Sustainability Transitions: A Multi-actor Perspective, Journal of Environmental Policy \& Planning, 18(5), 628-649. doi: 10.1080/1523908X.2015.1112259

Bakker, S. (2014). Actor rationales in sustainability transitions - Interests and expectations regarding electric vehicle recharging. Environmental Innovation and Societal Transitions, 13, 6074, https://doi.org/10.1016/j.eist.2014.08.002.

Bartel, C., Garud, R. (2009). The Role of Narratives in Sustaining Organizational Innovation. Organization Science, 20(1), 107-117, DOI: 10.1287/orsc.1080.0372.

Bernardi, L., Huinink, J., Settersten, R.A. (2018). The life course cube: A tool for studying lives, Advances in Life Course Research, in press. https://doi.org/10.1016/j.alcr.2018.11.004.

Bruner, J. (1986). Actual Minds, Possible Worlds. Harvard University Press, Cambridge, MA, 222 p. ISBN 9780674003668.

Bögel, P.M., Upham, P. (2018). The role of psychology in sociotechnical transitions literature: A review and discussion in relation to consumption and technology acceptance, Environmental Innovation and Societal Transitions, 28, 122-136. doi: 10.1016/j.eist.2018.01.002.

Corley, K., Gioia, D. (2004). Identity ambiguity and change in the wake of a corporate spin-off. Administrative Science Quarterly, 49, 173-208.

Czarniawska, B. (1997). Narrating the Organization: Dramas of Institutional Identity. University of Chicago Press, Chicago, IL, 242 p. ISBN 9780226132297.

de Haan, F., Rotmans, J. (2018). A proposed theoretical framework for actors in transformative change', Technological Forecasting \& Social Change, 128, 275-286.

de Vries, B., Blando, J., Southard, P. and Bubeck, C. (2001). The times of our lives, in Narrative gerontology: Theory, research, and practice, G. Kenyon, P. Clark, and B. De Vries (Eds.), New York: Springer, 137-158. ISBN 978-0826113894. 
de Vries, B., Suedfeld, P., Krell, R., Blando, J., Southard, P. (2005). The Holocaust as a context for telling life stories. The International Journal of Aging and Human Development, 60(3), 213228, https://doi.org/10.2190/TFHA-D5K5-KQKK-8DE4.

de Vries, B. (2013). Lifelines: A review of content and context. The International Journal of Reminiscence and Life Review, 1(1), 31-35.

de Vries, B., LeBlanc, A., Frost, D., Alston-Stepnitzc, E., Stephenson, R., Woodyatte, C. (2017). The relationship timeline: A method for the study of shared lived experiences in relational contexts. Advances in Life Course Research, 32, 55-64, https://doi.org/10.1016/j.alcr.2016.07.002.

Easterby-Smith, M., Thorpe, R., Jackson, P. (2008). Management Research. London: SAGE.

Eisenhardt, K.M. (1989). Building theories from case study research. Academy of Management Review, 14, 532-550. https://doi.org/10.2307/258557

Elder, G. (1973). Linking Social Structure and Personality. American Behavioral Scientist, 16(6), 785-800, https://doi.org/10.1177/000276427301600601.

Elder, G. (1994). Time, Human Agency, and Social Change: Perspectives on the Life Course. Social Psychology Quarterly, 57(1), 4-15, doi: 10.2307/2786971.

Elder, G. (1998). The life course as developmental theory. Child Development, 69, 1-12, doi: $10.2307 / 1132065$.

Fischer, L.B., Newig, J. (2016). Importance of actors and agency in sustainability transitions: A systematic exploration of the literature. Sustainability, 8. https://doi.org/10.3390/su8050476

Frantzeskaki, N., Wittmayer, J., Loorbach, D. (2014). The role of partnerships in 'realising' urban sustainability in Rotterdam's City Ports Area, The Netherlands, Journal of Cleaner Production, 65, 406-417.

Fuenfschilling, L., Truffer, B. (2016). The interplay of institutions, actors and technologies in socio-technical systems - An analysis of transformations in the Australian urban water sector. Technological Forecasting and Social Change, 103, 298-312, https://doi.org/10.1016/j.techfore.2015.11.023.

Gazheli, A., Antal, M., van den Bergh, J. (2015) The behavioral basis of policies fostering longrun transitions: Stakeholders, limited rationality and social context', Futures, 2015, 69, 14-30. doi: 10.1016/j.futures.2015.03.008.

Geels, F., Schot, J. (2007). Typology of sociotechnical transition pathways. Research Policy, 36(3), 399-417, https://doi.org/10.1016/j.respol.2007.01.003.

Gehman, J., Glaser, V.L., Eisenhardt, K.M., Gioia, D., Langley, A., Kevin G. Corley, K.G. (2018). Finding Theory-Method Fit: A Comparison of Three Qualitative Approaches to Theory Building. Journal of Management Inquiry, 27(3), 284-300. doi: 10.1177/1056492617706029/journals.sagepub.com/home/jmi 
Giddens, A. (1984). The Constitution of Society, University of California Press, Berkeley, CA, 402 p. ISBN 9780520052925.

Gioia, D., Corley., K., Hamilton, A. (2012). Seeking Qualitative Rigor in Inductive Research: Notes on the Gioia Methodology. Organizational Research Methods, 16(1) 15-31, https://doi.org/10.1177/1094428112452151.

Glaser B. (1992). Basics of Grounded Theory Analysis. Sociology Press, Mill Valley, California.

Glaser, B., Strauss, A. (1967). The discovery of grounded theory: Strategies for qualitative research. Chicago, IL: Aldine, 282 p. ISBN 978-0202302607.

Heinz, W., Huinink, J., Swader, C. S., Weyman, A. (2009). Fundamental conceptual frameworks. General introduction. In W. Heinz, J. Huinink, \& A. Weymann (Eds.). The life course reader: Individuals and society across time (pp. 15-30). Frankfurt/M: Campus.

Jang, Y., Haley, W. E., et al. (2002). Life events and stress, in Encyclopedia of aging, D. Ekerdt, R. Applebaum, K. Holden, S. Post, K. Rockwood, and R. Schulz (Eds.), New York: Macmillan Reference USA, 748-789. ISBN 978-0028654720.

Kemp, R., Schot, J., Hoogma, R. (1998). Regime shifts to sustainability through processes of niche formation: the approach of strategic niche management. Technology Analysis \& Strategic Management 10, 175-195.

Kern, F. (2015). Engaging with the politics, agency and structures in the technological innovation systems approach, Environmental Innovation and Societal Transitions, 16, 67-69. doi: http://dx.doi.org/10.1016/j.eist.2015.07.001

Koehrsen, J. (2018) Religious agency in sustainability transitions: Between experimentation, upscaling, and regime support, Environmental Innovation and Societal Transitions, 27, 4-15.

Kvale, S. (1996). InterViews: An Introduction to Qualitative Research Interviewing. Sage Publications, London, 344 p. ISBN 978-0803958203.

Köhler, J., Geels, F.W., Kern, F., Markard, J., Wieczorek, A., Alkemade, F., Avelino, F., Bergek, A., Boons, F., Fünfschilling, L., Hess, D., Holtz, G., Hyysalo, S., Jenkins, K., Kivimaa, P., Martiskainen, M., McMeekin, A., Mühlemeier, M.S., Nykvist, B., Onsongo, E., Pel, B., Raven, R., Rohracher, H., Sandén, B., Schot, J., Sovacool, B.K., Turnheim, B., Welch, D., Wells, P., 2019. An agenda for sustainability transitions research: State of the art and future directions. Environmental Innovation and Societal Transitions 1-32. https://doi.org/10.1016/j.eist.2019.01.004

Le Blanc, D. (2015). Towards Integration at Last? The Sustainable Development Goals as a Network of Targets. Sustainable Development, 23, 176-187. doi: 10.1002/sd.1582

Levy, R., Bühlmann, F. (2016). Towards a socio-structural framework for life course analysis. Advances in Life Course Research, 30, 30-42, https://doi.org/10.1016/j.alcr.2016.03.005. 
Lincoln Y.S., Guba E.G. (1985). Naturalistic Inquiry. Sage Publications, Beverley Hills, California.

Loorbach, D., Avelino, F., Haxeltine, J., Wittmayer, T., O'Riordan, P., Weaver, P., Kemp, R. (2016). The economic crisis as a game changer? Exploring the role of social construction in sustainability transitions. Ecology and Society, 21(4), 15, http://dx.doi.org/10.5751/ES-08761210415.

Loorbach, D., Frantzeskaki, N. and Avelino, F. (2017). Sustainability transitions research: transforming science and practice for societal change, Annual Review of Environmental Resources, 42(1), 599-626. doi: https://doi.org/10.1146/annurev-environ-102014-021340

MacLeod, M., Davidson, E. (2007). Organizational storytelling and technology innovation. Proceedings of the 40th Hawaii International Conference on System Sciences.

Markard, J., Raven, R., Truffer, B. (2012). Sustainability transitions: An emerging field of research and its prospects, Research Policy, 41(6), 955-967. doi: 10.1016/j.respol.2012.02.013

Mayer, K.U. (2019). On heuristics, theoretical foundations, accounting schemes and theories, Advances in Life Course Research, in press. https://doi.org/10.1016/j.alcr.2019.04.007

Mercure, J-F., Pollitt, H., Bassi, A., Viñuales, J., Edwards, N. (2016). Modelling complex systems of heterogeneous agents to better design sustainability transitions policy, Global Environmental Change, 37, 102-115, https://doi.org/10.1016/j.gloenvcha.2016.02.003.

Mitchell, B. (2013). Life course theory. International encyclopedia of marriage and the family. Available online: http://www.encyclopedia.com/doc/1G2-3406900275.html (accessed on 29.11.17)

Mortimer, J.T., Shanahan, M.J. (2003). Handbook of the life course. Springer.

Mossberg, J., Söderholm, P., Hellsmark H., Nordqvist, S. (2018). Crossing the biorefinery valley of death? Actor roles and networks in overcoming barriers to a sustainability transition, Environmental Innovation and Societal Transitions, 83-101. doi: 10.1016/j.eist.2017.10.008.

Patton, M. (2002). Qualitative evaluation and research methods (3rd ed.). Newbury Park, CA: Sage.

Pentland, B. (1999). Organizations as networks of action, in Variations in Organization Science: In Honor of Donald T. Campbell, J. Baum, B. McKelvey, (Eds.), Sage, Thousand Oaks, CA. 237253. ISBN 978-0761911265.

Pesch, U. (2015). Tracing discursive space: Agency and change in sustainability transitions. Technological Forecasting and Social Change, 90, 379-388. doi: 10.1016/j.techfore.2014.05.009. 
Pesch. U., Vernay, A-L., van Bueren, E., Iverot, S.P. (2017). Niche entrepreneurs in urban systems integration: On the role of individuals in niche formation, Environment and Planning A, 49(8), 1922-1942. doi: 10.1177/0308518X17705383

Rip, A., Kemp, R. (1998). 'Technological Change'. In S. Rayner, \& E. L. Malone (Eds.), Human choice and climate change. Vol. II, Resources and Technology (pp. 327-399). Columbus, Ohio: Battelle Press.

Rockström, J., Steffen, W., Noone, K., Persson, Å., Chapin, F.S., Lambin, E., Lenton, T.M., Scheffer, M., Folke, C., Schellnhuber, H.J., Nykvist, B., de Wit, C.A., Hughes, T., van der Leeuw, S., Rodhe, H., Sörlin, S., Snyder, P.K., Costanza, R., Svedin, U., Falkenmark, M., Karlberg, L., Corell, R.W., Fabry, V.J., Hansen, J., Walker, B., Liverman, D., Richardson, K., Crutzen, P., Foley, J., 2009. Planetary boundaries: Exploring the safe operating space for humanity. Ecology and Society, 14. https://doi.org/10.5751/ES-03180-140232

Schot, J., Geels, F.W. (2008). Strategic niche management and sustainable innovation journeys: theory, findings, research agenda, and policy. Technology Analysis \& Strategic Management 20, 537-554.

Shaw, A., Burch, S., Kristensen, F., Robinson, J., Dale, A. (2014). Accelerating the sustainability transition: Exploring synergies between adaptation and mitigation in British Columbian communities. Global Environmental Change, 25, 41-51. https://doi.org/10.1016/J.GLOENVCHA.2014.01.002

Settersten, R. (1999). Lives in time and place: the problems and promises of developmental science. Amityville, NY: Baywood Publishing Company, Inc., 318 p. ISBN 0895032007.

Stephenson, J. (2018). Sustainability cultures and energy research: An actor-centred interpretation of cultural theory, Energy Research \& Social Science, 44, 242-249.

Stirling, A. (2014). Transforming power: Social science and the politics of energy choices, Energy Research \& Social Science, 1, 83-95.

Thapar, S., Sharma, S., Verma, A. (2019). Analysis of factors impacting wind and solar sectorsChallenges to sustainable development (Four Country Study). Sustainable Development, 1-31. doi: 10.1002/sd.1940.

Upham, P., Lis, A., Riesch, H., Stankiewicz, P. (2015). Addressing social representations in sociotechnical transitions with the case of shale gas. Environmental Innovation and Societal Transitions, 16, 120-141, https://doi.org/10.1016/j.eist.2015.01.004.

Upham, P., Dütschke, E., Schneider, U., Oltrad, C., Salad, R., Lores, M., Klapper, R., Bögel, P. (2018). Agency and structure in a sociotechnical transition: Hydrogen fuel cells, conjunctural knowledge and structuration in Europe. Energy Research \& Social Science, 37, 163-174, https://doi.org/10.1016/j.erss.2017.09.040. 
van der Vleuten, E. (2018). Radical change and deep transitions: Lessons from Europe's infrastructure transition 1815-2015, Environmental Innovation and Societal Transitions, doi: https://doi.org/10.1016/j.eist.2017.12.004.

Wittmayer, J.M., Avelino, F., van Steenberg, F., Loorbach. D. (2017). Actor roles in transition: Insights from sociological perspectives, Environmental Innovation and Societal Transitions, 24, 45-56. doi: 10.1016/j.eist.2016.10.003.

Zeiger, B., Gunton, T., Rutherford, M. (2019). Toward sustainable development: A methodology for evaluating environmental planning systems. Sustainable Development, 27, 13-24. doi: $10.1002 / \mathrm{sd} .1852$. 
Figures and tables

Table 1. Actor categories

\begin{tabular}{|c|c|c|c|c|c|c|}
\hline Category & $\mathbf{N}$ & $\begin{array}{c}\text { Male } \\
{[\mathbf{N}]}\end{array}$ & $\begin{array}{c}\text { Female } \\
{[\mathbf{N}]}\end{array}$ & $\begin{array}{c}\text { Possible } \\
\text { subsystem: Food } \\
{[\mathbf{N}]}\end{array}$ & $\begin{array}{c}\text { Possible } \\
\text { subsystem: } \\
\text { Energy } \\
{[\mathbf{N}]}\end{array}$ & $\begin{array}{c}\text { Sustainability or } \\
\text { environmental } \\
\text { degree(s) }\end{array}$ \\
\hline $\begin{array}{c}\text { NGO actor } \\
\begin{array}{c}\text { Sustainability } \\
\text { professional in } \\
\text { industry }\end{array}\end{array}$ & 4 & 0 & 4 & - & - & 4 \\
\hline Public actor & 2 & 1 & 3 & 2 & 1 & 2 \\
\hline Academic & 2 & 1 & 1 & 1 & - & 2 \\
\hline Entrepreneur & 2 & 1 & 1 & 1 & 1 & 0 \\
\hline Green consumer & 2 & 2 & 0 & - & - & 0 \\
\hline Total & $\mathbf{1 6}$ & 6 & 10 & 3 & 5 & 9 \\
\hline
\end{tabular}

Table 2. Overview of second order themes, first order concepts and representative quotations.

\begin{tabular}{|c|c|c|}
\hline $\begin{array}{l}\text { Second order } \\
\text { theme }\end{array}$ & $\begin{array}{c}\text { First-order } \\
\text { concept }\end{array}$ & Representative quotations \\
\hline \multirow{3}{*}{$\begin{array}{l}\text { Upbringing and } \\
\text { education }\end{array}$} & $\begin{array}{l}\text { Connection to } \\
\text { nature in their } \\
\text { early years }\end{array}$ & $\begin{array}{l}\text { "This somehow started in early childhood, when I played around in the forest a } \\
\text { lot. Today I also understand the significance of forests through my work. I mean, } \\
\text { the rainforests are irreplaceable, and the northern coniferous forests act as carbon } \\
\text { sinks. But I still think that forests are also extremely important places for calming } \\
\text { down and for healthy living." (NGO actor 1) }\end{array}$ \\
\hline & $\begin{array}{c}\text { Experiences } \\
\text { during studies }\end{array}$ & $\begin{array}{l}\text { "When I got into university, I thought that I need to do something for it [climate } \\
\text { change]. I guess, it was some sort of calling. In the University of Helsinki, my } \\
\text { major was environmental change and policy. In that major, you need to read a lot } \\
\text { from different viewpoints, so you learn a lot. So, I was very eager to tackle the } \\
\text { climate change." (Sustainability professional 1) }\end{array}$ \\
\hline & $\begin{array}{l}\text { Professional } \\
\text { development }\end{array}$ & $\begin{array}{l}\text { "Sustainability issues are part of my professional position. For example, at the } \\
\text { Center for economic development, the focus was on top soil. But later [the center] } \\
\text { had a wider focus on environmental policy and waste management, for example. } \\
\text { Today I'm working with the same issues, but now the approach is through NGOs." } \\
\text { (NGO actor 3) }\end{array}$ \\
\hline \multirow{3}{*}{$\begin{array}{l}\text { Awakening } \\
\text { moments }\end{array}$} & $\begin{array}{c}\text { Seeing the } \\
\text { deprivation of } \\
\text { nature }\end{array}$ & $\begin{array}{l}\text { "Before the coal industry had all these purification systems, these emissions } \\
\text { caused coniferous trees to drop their needles. At the time, in Kokemäki [a town in } \\
\text { southwestern Finland], XYZ [a chemical industry group, name removed for } \\
\text { reasons of confidentiality] had a fertilizer-manufacturing plant, and when we } \\
\text { traveled through Kokemäki to Pori, we could actually see these black forests. } \\
\text { Actually, they weren't black - they were frayed. The needles of the pine trees were } \\
\text { half bald." (NGO actor 2) }\end{array}$ \\
\hline & $\begin{array}{c}\text { Awakening } \\
\text { concern about the } \\
\text { future }\end{array}$ & $\begin{array}{l}\text { "There is the stream of Haaga [stream in the district of Haaga in Helsinki]. As } \\
\text { kinds, we thought it was in a bad shape. There were a lot of oil and trash on the } \\
\text { surface. If you wanted to build a ferry, you always found material to build it. At } \\
\text { the time I was about five or six years old. Somehow it was horrible." } \\
\text { (Sustainability professional 2) }\end{array}$ \\
\hline & $\begin{array}{l}\text { Remarkable life } \\
\text { event that } \\
\text { adjusted the } \\
\text { actor's world } \\
\text { view }\end{array}$ & $\begin{array}{l}\text { "I had promised to study Finnish corporations in the Amazon. Then, of course, } \\
\text { first I needed to figure out which firms were relevant for the study. Among others, } \\
\text { there was XYZ [a consulting firm, name removed for reasons of confidentiality], } \\
\text { which had done some sort of forest consulting over there; then there was a Valmet } \\
\text { Oy factory in São Paulo, or somewhere nearby, and they sold tractors for removing } \\
\text { the rainforest. Several paper companies were also operating there. At the time, } \\
\text { Finland's export, or international, business, was quite biased toward the forestry } \\
\text { industry. Okay, then I did most of my interviews for the study in or near São Paolo, } \\
\text { but since part of the travel plan was to go to the Amazon, I also went there. We } \\
\text { traveled via riverboat from the Atlantic coast (from Belém) a couple of days }\end{array}$ \\
\hline
\end{tabular}


upstream to Manaus. From there I traveled to the middle of nowhere. I mean, Manaus is already in the middle of nowhere, but it's still a pretty large city in the Amazon. From there I traveled even farther; I flew in a small plane for a couple of hours to really the middle of nowhere, to a small town called Rio Branco, where no one spoke anything but Portuguese. Fortunately I had a translator with me. I also did interviews in Rio Branco, and I had already met with a few administrative representatives. I had formed kind of a general view about the phenomenon. Okay, so now we get into the core of this issue. At the time, the deforestation of the Amazon was all over the news in Western countries, since, for example, the Body Shop had a campaign called 'Stop the burning.' This means that within environmentally conscious circles, people acknowledged that the Amazon rainforest was being destroyed for cultivation. At the time the understanding was that the rainforests of the Amazon are equivalent to the lungs of the Earth; of course, now we know that this is not the case. But at the time, the understanding was that the Amazon was the lungs, and people thought that the lungs of the Earth were now being chopped down. At the time, climate change was not a topic, but the label of destroying an area of rainforest equaling the area of several football fields a day for cultivation was bad. The method they used to remove the rainforest was called 'slash and burn,' so the rainforest was actually being burned down in order to acquire farmland. Then I was there, and I saw how the rainforest was being burned down and turned into farmland, and I saw how the neighboring areas had already been changed into farmland. The people who did this came from southern Brazil, which was already overpopulated then - not to mention how overpopulated the place is today. So they had left southern Brazil with the hope of a better life and for subsidies from the Brazilian government. Of course, the subsidies were really small-I mean, my travel expenses were big compared to these subsidies. But anyway, they left for the Amazon because they got money from the government to 'remove the rainforest.' So one viewpoint for looking at this issue is to think that Brazil subsidized the deforestation of its own rainforest. I mean, that's one viewpoint. Another viewpoint is from the tractor seller's point of view, like 'Okay, there will be fields. There will be a need for tractors, so there's a market.' This was the viewpoint of one Finnish company. Then there was this viewpoint of the actual operator of the process [of cutting down the trees]. [The job] was a possibility for a better life, or at least for a more independent life, in any case. But all in all, it was a possibility to achieve a normal life through farming. And Westerners moralized this whole thing in their heads. So when you think about this, everyone was actually acting rationally from their own viewpoint. So the Body Shop campaign, the Westerners' ideas, the family who's run away from the favela, the tractor seller, and the Brazilian government-they all acted reasonably, according to their own viewpoints. Still, the end result was that the rainforest was being destroyed. So at the beginning, I didn't realize what was going on there, since at the time - during my studies or anywhere else - I'd never heard the phrase 'external costs.' Then at some point, I learned that this thing was an 'external cost,' and I don't even remember how I discovered these basic concepts from environmental economics. Probably from some article, but how I found that, I don't remember, since at the time there was no Internet. But somewhere I found this information, and then I understood that, within this operation, the external costs were invisible. For that reason, stupid things were being done at the system level, even though at the individual or stakeholder level, things made sense; the price was the destruction of the environment, or contamination, if those were thought of as emissions. This was actually the starting point for me to get in touch with the terminology, and then I started to think, 'None of this seems to make sense, but still, people are doing things this way. Why are things done like this?' So basically, I've been solving this problem ever since." (Academic 1)

"When I lived abroad, I often took yoga and meditation classes on Sundays, since, especially at the beginning, I didn't have as big a social circle as I'd had in Finland. I thought that was a bit odd, and I wondered if I'd gone there just to sit every Sunday at one woman's meditation class. I found [the situation] really weird, but then I noticed how I'd also gotten a lot out of [the yoga class]. I wasn't sure what I'd actually gotten from it, but I knew that there was something. I remember that, after I'd been going to the classes every Sunday for about two or three years, I was spending the time thinking about the meaning of life and what our bigger purpose 


\begin{tabular}{|c|c|c|}
\hline & & $\begin{array}{l}\text { was in life. Then one Sunday I came home, and I started to write in my journal. I } \\
\text { did that quite a bit already, but then I also started to take these flip charts out, and } \\
\text { I just completely filled my house with these flip charts, where I wrote down my } \\
\text { mission in life. I was very confused, since something like 'The meaning of life is } \\
\text { to save the world from environmental catastrophe by using human potential' came } \\
\text { up. I looked at the text and was like, 'This is kind of frightening, since my current } \\
\text { professional career has almost nothing to do with this. This all sounds nice, but it's } \\
\text { out of my reach.' I just thought how my professional path didn't match with this } \\
\text { goal. But then I also started to think how the meaning of life was now written down } \\
\text { on these charts, and I thought that this would be a great dream to pursue for the } \\
\text { rest of my life. After that moment, I started to somehow more actively take notice } \\
\text { of this field [i.e., sustainability] and to create links to the field. I started to be } \\
\text { partially aware of this thing, and I experienced this personal awakening." } \\
\text { (Academic 2) }\end{array}$ \\
\hline \multirow[t]{2}{*}{$\begin{array}{c}\text { Belief in a } \\
\text { sustainable future }\end{array}$} & $\begin{array}{l}\text { Belief that the } \\
\text { future will turn } \\
\text { out better }\end{array}$ & $\begin{array}{l}\text { "The importance of sustainability is definitely increasing. After the Paris } \\
\text { agreement, the future looks brighter to me." (NGO actor 4) }\end{array}$ \\
\hline & $\begin{array}{l}\text { Will to create a } \\
\text { better world for } \\
\text { future } \\
\text { generations }\end{array}$ & $\begin{array}{l}\text { "I find education extremely important, since I tend to spend a lot of time with } \\
\text { kids." (Public actor 2) }\end{array}$ \\
\hline \multirow[t]{2}{*}{$\begin{array}{l}\text { Critical of the } \\
\text { existing system }\end{array}$} & $\begin{array}{l}\text { Criticism of } \\
\text { capitalism }\end{array}$ & $\begin{array}{l}\text { "If you think about the big picture after the industrial revolution, I think we've } \\
\text { gone too far with this capitalistic mode of excessive growth and the excessive } \\
\text { industrial profit-seeking world view." (Academic 2) }\end{array}$ \\
\hline & $\begin{array}{l}\text { Criticism of } \\
\text { consumption }\end{array}$ & $\begin{array}{l}\text { "Oh boy, I always think that, as a consumer, like, 'Okay, I don't consume,' but } \\
\text { then I see these 'Wish [Wish.com] Finland' Facebook groups with } 100,000 \\
\text { members, for example, who are excited about cheap copies [of brand products]." } \\
\text { (Sustainability professional 2) }\end{array}$ \\
\hline \multirow[t]{2}{*}{$\begin{array}{l}\text { Intrinsic } \\
\text { motivation } \\
\text { overcomes } \\
\text { collective } \\
\text { expectations }\end{array}$} & $\begin{array}{c}\text { Intrinsic } \\
\text { motivation results } \\
\text { in deliberative } \\
\text { actions }\end{array}$ & $\begin{array}{l}\text { "The last year [at Finfood] was really difficult whenever I had to act against my } \\
\text { values, and I thought, 'Is this really something that I can do?"' (Entrepreneur 1) }\end{array}$ \\
\hline & $\begin{array}{l}\text { Belief in oneself } \\
\text { helps one to stay } \\
\text { resilient }\end{array}$ & $\begin{array}{l}\text { "If I were to stop doing this for some reason, I would tear every part of myself } \\
\text { away along with it. For example, my friends are largely doing these same things, } \\
\text { too." (NGO actor 2) }\end{array}$ \\
\hline \multirow[t]{2}{*}{$\begin{array}{l}\text { Feeling of } \\
\text { inadequacy }\end{array}$} & $\begin{array}{c}\text { Need to set } \\
\text { personal } \\
\text { boundaries }\end{array}$ & $\begin{array}{l}\text { "Somehow I've recognized that we only have } 24 \text { hours in a day, which means that } \\
\text { we have to make conscious choices about our careers and personal lives. We need } \\
\text { to strictly protect our resources. I'd really like to do a lot more. I'd like to be able } \\
\text { to divide myself into five versions of me, and I'd like to work day and night, and } \\
\text { I feel bad, since I can't do more." (Academic 2) }\end{array}$ \\
\hline & $\begin{array}{l}\text { Belief that one's } \\
\text { actions are not } \\
\text { enough }\end{array}$ & $\begin{array}{l}\text { "...but when you know how much more you should do, your bad conscience is } \\
\text { always present. I mean, of course I do a lot, but still..." (NGO actor } 3 \text { ) }\end{array}$ \\
\hline \multirow[t]{2}{*}{$\begin{array}{l}\text { Value-action } \\
\text { coherence }\end{array}$} & $\begin{array}{l}\text { Sustainability } \\
\text { actions are self- } \\
\text { evident and part } \\
\text { of normal life }\end{array}$ & "So, everything here [in the office] is recycled." (Entrepreneur 1) \\
\hline & $\begin{array}{l}\text { Values reflect } \\
\text { behavior }\end{array}$ & $\begin{array}{l}\text { "As an organizational leader, I'm ambitious about our organization, and of course } \\
\text { I'm proud of all the results we've been able to achieve. But all the time I've been } \\
\text { here, I've always highlighted the fact that we're all doing this together. It doesn't } \\
\text { matter who does something, as long as we're able to do something good." (NGO } \\
\text { actor 4) }\end{array}$ \\
\hline \multirow[b]{2}{*}{$\begin{array}{l}\text { Socio-physical } \\
\text { coherence }\end{array}$} & Healthy lifestyle & $\begin{array}{l}\text { "Things that influence on my life and decisions are family and healthy lifestyle." } \\
\text { (Sustainability professional 1) }\end{array}$ \\
\hline & Yoga & $\begin{array}{l}\text { "Many people who are associated with organic farming also do yoga, and so do I. } \\
\text { I'm a yoga instructor for two yoga groups. I assume that the central idea of yoga's } \\
\text { non-violence approach can be linked with the view of avoiding pesticides in } \\
\text { organic farming." (NGO actor 1) }\end{array}$ \\
\hline
\end{tabular}


Physical activity "My environmental consciousness has grown from a sensitivity toward natureor maybe from a love of nature — and from the fact that I feel so good when I'm in the forest, and of course when I'm at a lake or by the sea." (NGO actor 4)

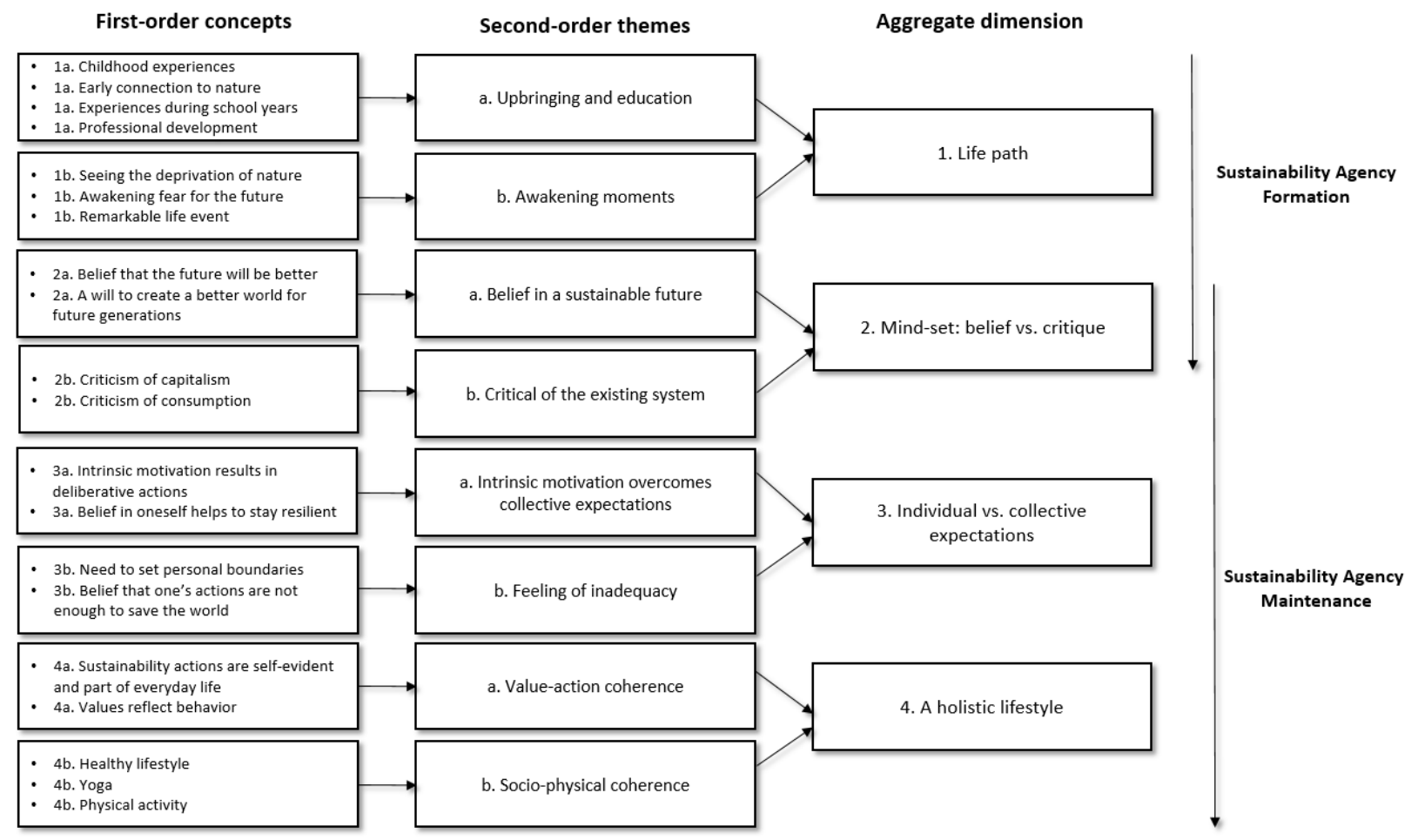

Figure 1. Data structure. 
Engagement to sustainability agenda

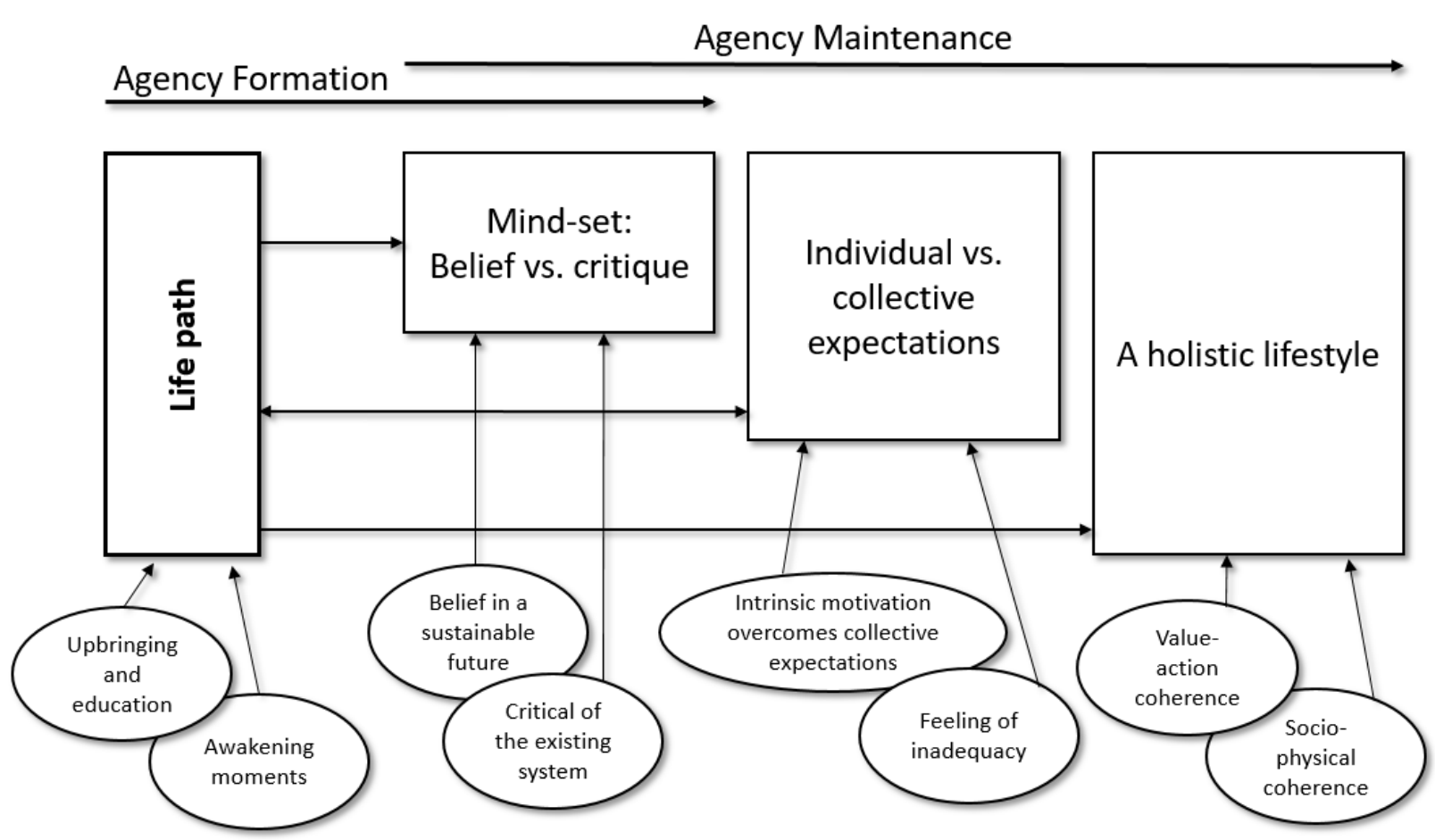

Figure 2. Grounded model of sustainability engagement. 